\title{
SOSIALISASI ; PERSEPSI ORANG TUA TENTANG KEKERASAN TERHADAP ANAK DI KELURAHAN RENGAS PULAU KEC. MARELAN KOTA MEDAN
}

\author{
Maswita $^{1^{*}}$, Hasrita $^{2}$, Arifa Pratami ${ }^{3}$ \\ 1,Program Studi Hukum, Fakultas Hukum, Universitas Al-Azhar, Jl. Pintu Air IV No.214, Kwala \\ Bekala, Kec. Medan Johor, Kota Medan, Sumatera Utara 20143 \\ 2,Program Magister Manajemen, Fakultas Ekonomi, Universitas Islam Sumatera Utara, Jl. \\ Sisingamangaraja Kelurahan, Teladan Bar., Kec. Medan Kota, Kota Medan, Sumatera Utara 20217 \\ 3,Program Ekonomi Syariah, Fakultas Agama Islam, Universitas Islam Sumatera Utara, J1. \\ Sisingamangaraja Kelurahan, Teladan Bar., Kec. Medan Kota, Kota Medan, Sumatera Utara 20217
}

*Maswita.Maswita30@gmail.com

\begin{abstract}
ABSTRAK. Kegiatan pengabdian masyarakat ini, bertujuan untuk memberikan pemahaman kepada wanita dan ibu-ibu warga Kelurahan Rengas Pulau yang tergabung dalam Lembaga Pemberdayaan Perempuan dan Anak Wanita Sejati tentang kekerasan kepada anak supaya ibu-ibu memahami hal-hal yang termasuk dalam kekerasan terhadap anak dan mempunyai persepsi yang berkaitan dengan hak-hak anak. Kegiatan pengabdian ini dilakukan dengan metode penyuluhan dan simulasi. Hasil yang diperoleh setelah penyuluhan bahwa ibu-ibu semakin memahami tentang kekerasan dan cara pencegahan kekerasan terhadap anak serta cara melaporkan apabila terjadi kejadian kekerasan di lingkungan mereka. Saran apabila menemukan anak dengan kasus kekerasan agar segera melaporkan kepada orang tua atau kepada petugas yang berwenang.
\end{abstract}

Kata kunci: Kekerasan; Anak, Wanita , Persepsi.

ABSTRACT. This community service activity aims to provide an understanding to women and mothers of the Rengas Pulau Village. They are members of the Women's and Women's Empowerment Institute about violence against children so that mothers understand the things included in violence against children and perceive violence against children-relating to children's rights. This service activity is carried out using counseling and simulation methods. The results obtained after the counseling were that mothers understood more about violence, how to prevent violence against children, and how to report incidents of violence in their environment. Suggestions if you find a child with a case of violence to immediately report it to the parents or the authorized officer

Keywords: Violence, Child, Woman, Perception

\section{PENDAHULUAN}

World Health Organization (2002) menyebutkan bahwa, perilaku kekerasan terhadap anak adalah semua bentuk perlakuan menyakitkan secara fisik ataupun emosional, penyalahgunaan seksual, pelalaian, yang mengakibatkan cedera atau kerugian pada kesehatan anak, kelangsungan hidup anak, tumbuh kembang anak, atau martabat anak, yang dilakukan dalam konteks hubungan tanggung jawab.

Kekerasan terhadap anak adalah suatu bentuk tindakan atau perlakuan menyakitkan secara fisik maupun emosional, misalnya penyalahgunaan seksual, penyalahgunaan, penelantaran, yang mengakibatkan kerugian nyata ataupun potensial terhadap kesehatan anak, kelangsungan hidup anak, tumbuh kembang anak atau martabat anak (Permendikbud, 2015). Anak-anak yang dalam perkembangannya mengalami kekerasan akan mengalami kekurangan afeksi (kasih sayang orang tua mereka) misalnya pemarah, mudah sedih, sulit fokus dan mudah marah atau emosi tidak terkendali. Terjadinya kekerasan pada anak dipengaruhi oleh beberapa faktor yaitu peran keluarga/orang tua, berasal dari tingkah laku anak sendiri, lingkungan, media massa, sistem pengajaran disekolah dan budaya (Kurniasari, 2015). Sehingga pentingnya peran orang tua, sebagai sumber keamanan bagi perkembangan anak, tempat ia belajar dan menyatakan diri sebagai makhluk sosial.

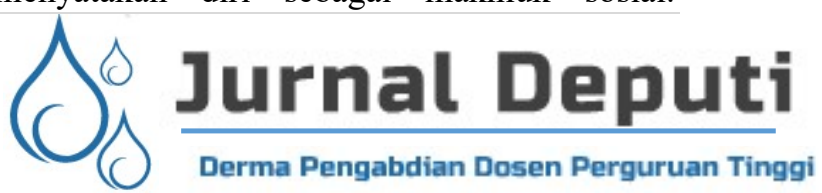


Fitriana, 2015). Padahal para orang tua, keluarga dan masyarakat turut serta bertanggung jawab dalam menjaga dan memelihara hak-hak anak tersebut sesuai dengan kewajiban yang telah dibebankan oleh hukum (Lilik Purwastuti, 2020). Demikian pula dalam rangka penyelenggaraan perlindungan anak, negara dan pemerintah bertanggung jawab menyediakan fasilitas dan aksesibilitas bagi anak, terutama dalam menjamin pertumbuhan dan perkembangannya secara optimal dan terarah.

Kekerasan pada anak merupakan fenomena yang kompleks dengan penyebab yang bermacam-macam. Faktor yang mempengaruhi persepsi orang tua (orang dewasa) tentang kekerasan pada umumnya adalah disebabkan informasi dan pengetahuan yang kurang tentang kekerasan terhadap anak. Sebahagian orang tua merasa bahwa anak adalah aset untuk membantu mencari nafkah dan berkewajiban membantu mengasuh adiknya, berkewajiban membantu pekerjaan rumah, bahkan kadang-kadang anak masih usia 6 atau 7 tahun sudah disuruh membantu pekerjaan rumah dan pekerjaan lainnya tanpa memberikan waktu kepada anak untuk bermain dan sebagainya. Sebahagian lagi orang tua menganggap kekerasan pada anak adalah hal yang wajar. Mereka beranggapan kekerasan adalah bagian dari mendisiplinkan anak, memberikan pengajaran kepada anak (Sri Rusiaty, 2021).

Sementara itu anak adalah seorang yang harus mendapatkan kasih sayang, asupan gizi yang baik dan seimbang, pendidikan, dan perlindungan. Perlu diketahui bahwa kekerasan yang terjadi pada anak dapat meninggalkan bekas seumur hidup. Bahkan, anak-anak dapat tumbuh dan berkembang dengan rasa takut dan dalam keadaan pikiran yang tidak jelas. Hal ini tentu mempengaruhi anak secara fisik dan psikis. Sebagian besar terjadi kekerasan terhadap anak di rumah anak itu sendiri dengan jumlah yang lebih kecil terjadi di sekolah, di lingkungan atau organisasi tempat anak berinteraksi

\section{METODE}

Kegiatan pengabdian kepada masyarakat ini menggunakan metode berupa penyuluhan pada kelompok wanita dan ibu-ibu yang tergabung dalam Lembaga Pemberdayaan Perempuan

$\mathbf{2 5}$ | P a g e dan Anak Wanita Sejati Kelurahan Rengas Pulau Kecamatan Medan Marelan Kota Medan. Dalam melaksanakan Penyuluhan pada program pengabdian masyarakat yang berjudul: "Sosialisasi Persepsi Orang tua Tentang Kekerasan Terhadap Anak melalui beberapa tahapan yang direncanakan.

1. Teridentifikasi materi penyuluhan tentang kekerasan terhadap Anak, Teridentifikasi alokasi waktu penyuluhan yang dibutuhkan, Teridentifikasi metode penyuluhan yang dilakukan. Teridentifikasi sumber, media dan alat penyuluhan yang digunakan. 2 . Penyusunan media dan hand out ; Tersusun bahan penyuluhan yang digunakan dalam bentuk power ponit, Tersusun hand out materi penyuluhan yang diberikan kepada peserta wanita dan ibu-ibu yang tergabung dalam kelompok Lembagaga Pemberdayaan Perempuan dan Anak Wanita Sejati. 3. Persiapan pelaksanaan : Menyiapkan bahan dan alat penyuluhan, Terkoordinasikan dengan pengurus lembaga, dan hal teknis lain yang dibutuhkan untuk penyuluhan, Penggandaan handout. Persiapan distribusi logistik penyuluhan.

\section{HASIL DAN PEMBAHASAN}

Kegiatan Penyuluhan ini dilaksanakan di Kantor Lembaga Pemberdayaan Perempuan dan Anak Wanita Sejati kelurahan Rengas Pulau Kecamatan Medan Marelan kota Medan yang dihadiri oleh 35 peserta yang didominasi oleh ibu-ibu. Pada kegiatan ini yang menjadi mitra yaitu kelompok wanita dan ibu-ibu rumah tangga yang tergabung dalam kelompok Lembaga Pemberdayaan Perempuan dan Anak Wanita Sejati. Peserta yang hadir merupakan mitra kegiatan pengabdian masyarakat sangat senang mengikuti kegiatan ini, hal ini terlihat dari banyaknya peserta yang hadir dan aktifnya peserta pada kegiatan ini dengan mengajukan berbagai pertanyaan dan pernyataan. Seperti yang dipaparkan oleh tiga orang peserta bahwa kekerasan kerap terjadi kepada anak seperti memukul anak sehingga menimbulkan bekas, tetapi orang tua selalu merasa itu adalah cara untuk mendisiplinkan anak-anak untuk patuh kepada orang tua. Selain itu, sulitnya warga untuk tidak melakukan kekerasan karena anak adalah aset orang tua dalam membantu bekerja dan menghasilkan uang. Seorang anak jika sudah putus sekolah harus membantu orang tua dalam pekerjaan rumah dan pekerjaan

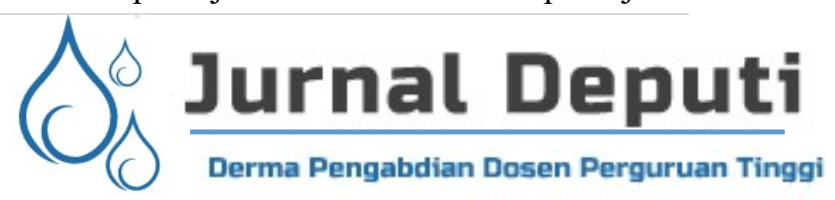


menghasilkan uang. Hal lain yang selalu terjadi adalah pada anak yang ditinggalkan ibunya untuk selamanya, lalu dia diasuh oleh neneknya dimana di rumah neneknya ada seorang paman yang masih belum menikah lalu terjadi kekerasan seksual. Kasus selanjutnya yang terjadi adalah dua orang anak yang ditinggal oleh kedua orang tuanya. Mereka terdiri dari seorang laki-laki dan seorang perempuan dimana dalam bertanggungjawab secara ekonomi adalah abangnya, pada kasus ini terjadi kekerasan sexual. Sebelum kegiatan pengabdian ini dilaksanakan, ada perbicangan bersama ibu ketua Lembaga Pemberdayaan Perempuan dan Anak Wanita Sejati kota Medan tentang situasi di kawasan kelurahan Rengas Pulau Kecamatan Marelan Kota Medan. Secara resmi beliau mengundang Fakultas Hukum Al Azhar untuk memberikan penyuluhan tentang pengetahuan dan pemahaman tentang kekerasan anak. Lembaga ini bermaksud supaya ibu-ibu warga Rengas Pulau memahami tentang kekerasan terhadap anak. Kekerasan kerap terjadi kepada anak karena anak dianggap mempunyai kewajiban dalam keluarga, dan apabila anak dalam asuhan orang dewasa maka orang dewasa selalu memanfaatkannya, seperti pemukulan dan perilaku sexual.
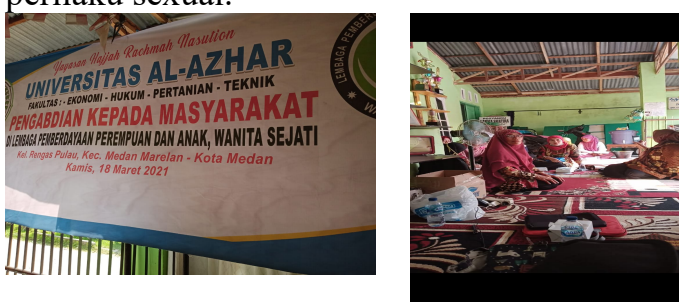

Gambar1.Kantor(a)Spanduk;(b) kata sambutan Ketua LPAWS

\section{KESIMPULAN}

Penutup pada kegiatan pengabdian ini adalah berupa simpulan yaitu adanya peningkatan pengetahuan dan pemahaman peserta tentang kekerasan terhadap anak yang selama ini menganggap anak berkewajiban membantu dan bekerja dalam ekonomi keluarga. Kekerasan dilakukan orang tua adalah hal yang biasa untuk mendisiplinkan anak dan memberi pembelajaran. Hal ini diketahui dari dibuatkannya komitmen ibu-ibu untuk selalu menjaga dirinya dan keluarganya dan tidak melakukan kekerasan terhadap anak. Dan jika mengetahui terjadi kekerasan terhadap anak di lingkungannya akan segera melaporkannya kepada pihak yang berwenang.

\section{DAFTAR PUSTAKA}

Fitriana, Y., Pratiwi, K., \& Sutanto, A.V. (2015). Faktor-faktor yang berhubungan dengan perilaku orang tua dalam melakukan kekerasan verbal terhadap anak usia pra-sekolah. Jurnal Psikologi Undip, 14(1), 81-93

Gultom, Maidin, 2015, Perlindungan Hukum terhadap Anak dalam Sistem Peradilan Pidana Anak di Indonesia, Bandung : Refika Aditama.

Kurniasari, Alit. (2015). Kekerasan Versus Disiplin Dalam Pengasuhan Anak. Jakarta: Jurnal Sosio Informa Vol. 1, No. 02, Mei - Agustus, 141-159

Komisi Nasional Perlindungan Anak (Komnas PA) mencatat peningkatan kasus kekerasan terhadap anak selama kurun 2020. "Meningkat 38 persen, jadi sangat menakutkan," ujar Ketua Komnas PA, Arist Merdeka Sirait, kepada wartawan pada Senin (4/1/2021). Kompas.com .

Lilik Purwastuti 2020. Perlindungan Hukum Terhadap Anak Sebagai Korban Eksploitasi Sex Komersial (ESKA) https://media. neliti.com/media /publications/43293-ID-perlindunganhukum-terhadap-anak-sebagai-korbaneksploitasi-seks-komersial-anak.pd

Setyawan, D. (2015). KPAI: Pelaku Kekerasan Terhadap Anak Tiap Tahun Meningkat.

Diakses dari www.kpai.go.id

Sri Rosiaty, 2021, Orang tua Kurang Memahami Tentang Kekerasan Terhadap Anak (Ketua lembaga Perlindungan Perempuan dan Anak Wanita Sejati Kota Medan).
WHO (2002) http://repository.uin- suska.ac.id/13949/8/7.\%20BAB\%20II_2 018168PSI.pdf 